\title{
Teachers' Experiences with School Choice: Clashing Logics in the Swedish Education System
}

\author{
Ulf Lundström ${ }^{1}$ and Karolina Parding ${ }^{2}$ \\ ${ }^{1}$ Department of Applied Educational Science, Umeå University, 90187 Umeå, Sweden \\ ${ }^{2}$ Department of Economy, Technology and Society, Luleå University of Technology, 97187 Luleå, Sweden
}

Correspondence should be addressed to Karolina Parding, karolina.parding@ltu.se

Received 18 October 2010; Revised 31 January 2011; Accepted 11 February 2011

Academic Editor: Vincent Dupriez

Copyright ( $) 2011$ U. Lundström and K. Parding. This is an open access article distributed under the Creative Commons Attribution License, which permits unrestricted use, distribution, and reproduction in any medium, provided the original work is properly cited.

\begin{abstract}
This paper explores the school choice reform in Sweden, a country where a drastic shift in education policy has taken place that includes fast expansion of market solutions and strong state support for competition. Although there are studies examining the school choice reform, few focus on the effects of this reform from a teacher perspective, especially so in the context of Sweden. To this end, this paper examines how Swedish upper secondary teachers in independent (private) and public schools experience their work in relation to school choice reform. This study uses qualitative interviews of 58 teachers from five municipal and three independent upper secondary schools. Its theoretical framework relies on Freidson's distinction between the logic of the profession, the bureaucracy, and the market. The findings indicate that the traditional position of teachers-a position that must negotiate the tension between the logic of the profession and the logic of the bureaucracy-is now in fact challenged by the logic of the market. This study argues that values linked to the logic of the market are imposed on the teachers, and these market values clash with the teachers' values, values based on the logic of the profession.
\end{abstract}

\section{Introduction}

This paper examines influence of market-oriented reforms on teachers, by shedding light on teachers' beliefs, values and experiences of the school choice reform. As with many other Western countries, the Swedish education system is currently undergoing major restructuring. For example, school choice reform has been introduced even though education in Sweden has traditionally been a public issue and students have by default been enrolled in the (municipal) school in the area where they live. During the 1990s, the state promoted school choice and competition through legislation and funding of independent (private) schools $[1,2]$. At the same time, reforms that addressed decentralisation and devolution of financial resources were implemented. As a result, in Sweden the expansion of upper secondary independent schools has in a short period increased rapidly, from attracting $1.7 \%$ to attracting $21.7 \%$ of all students between 1993 and 2010 (see Figure 1). This means that schools today, regardless of whether they are municipal or independent, compete for students. It can be argued that this competition will increase even more as the number of upper secondary students, due to changing demographics, will be reduced in the next few years.

Although the effects of school choice on teachers are seldom directly examined, the effects of school choice are described on an overriding level where the effects on teachers are described as one of many issues. However, there are some studies that directly discuss the reform in relation to teachers. Chubb and Moe [3,4] argue that private schools promote school autonomy and "enhance its own organizational wellbeing" [3] which is beneficial for teachers as it gives them greater influence over their work and thereby higher work satisfaction. Hoxby [5] also sees school choice as positive for the teaching profession, claiming that the issue of choice and competition in fact "would change the teaching profession by raising the demand for teachers with math and science skills, and raising the demand for teachers who make extra 


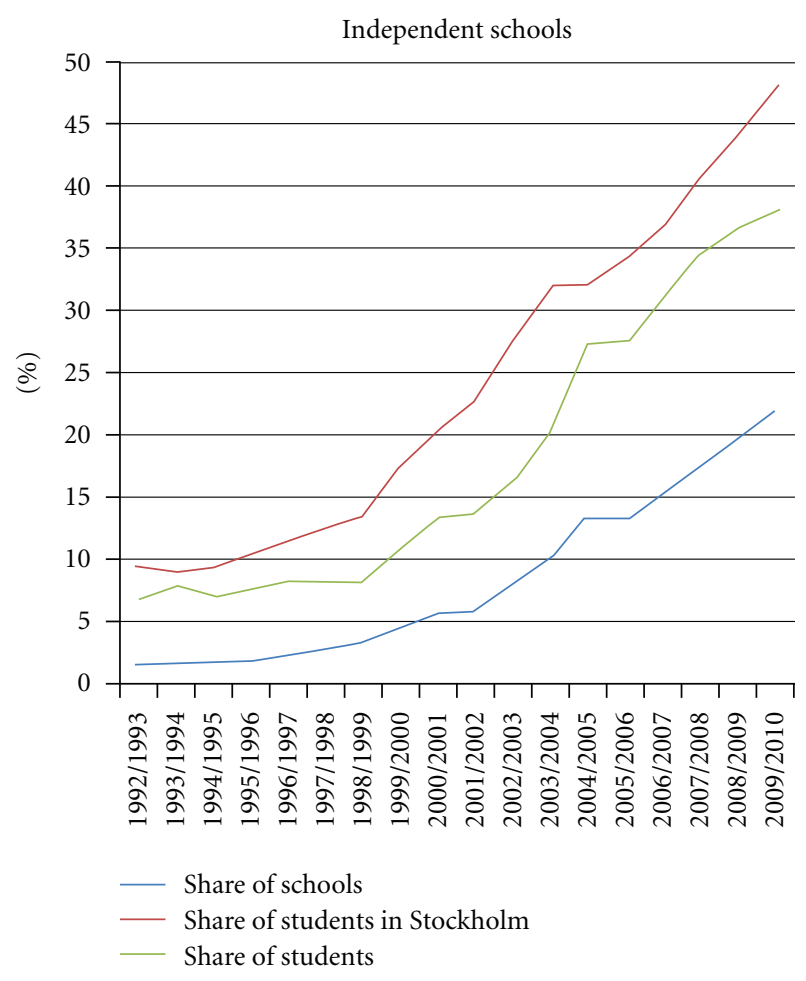

FIgURE 1: Independent schools in Sweden: share of students, schools and students in Stockholm, 1992-2010 (The Swedish National Agency for Education 2010).

effort and assume responsibility." At the same time, Hoxby [5] points out some features in the US school choice programmes that make them problematic: schools choice programs are less funded than regular public schools, school choice programmes are unsatisfactorily integrated with state school finance, and school choice is not universal in the respect that all parents (students) and all regular schools cannot participate.

There is a strand of research that is more critical regarding effects of school choice on teachers' work. These studies often place the marketization of the education system in the contexts of neoliberalism, new public management, managerialism, and performativity. These values or ideologies frame most of the discussions about teachers' work, yet these values or ideologies often are in direct conflict with democratic educational values, equity, and the public good (c.f., [611]). These researchers often describe negative effects for teachers as work intensification, lower teacher discretion, and lack of trust in the profession. Ball [7], for instance, claims that the current "epidemic of reform $[\cdots]$ does not only change what people, as educators, scholars, and researchers do, it changes who they are". Helsby [8] describes how educational reform such as school choice creates a new work order for teachers. Walsh [10] is another example of this group of critical researchers. He discusses the UK and claims that the recent marketization reforms have led to a transformation of teachers' practices. Walsh argues that the current supervisory management culture marginalizes discourses of egalitarianism and rejects core values of teachers' work, which deals with fostering intellectual growth among the students. In addition, he claims that the recent reforms transform teaching and learning in schools, reducing teachers to compliant technicians and performers, which stands in contrast to the traditional ethos of professionalism.

The Swedish research literature on the effects of school choice on teachers is limited, especially concerning the recent development at upper secondary level. In fact, Fredriksson $[12,13]$ is quite unique in focusing on the Swedish school choice reform in relation to teachers' work. He claims that teachers change their attitudes and behaviours as a result of the reform, changes that reflect the "market orientation" of the reform. On a general level, there are a number of different perspectives. Some studies examine policy changes at a general political level [14-17]. Others focus on effects such as equality of education [18], parent/student choices [19, 20], or grade inflation [21]. The results are contradictory regarding the effects of school competition on student achievement [22-24], but Bunar [18] claims that the government is pursuing the marketization policy "solely on an ideological basis" (as is also the case in other countries, according to Ladd [25]).

Even if school choice is a global phenomenon, it is difficult to make cross-country applications of results as education systems varies greatly between countries in form of differing historical, social, economical, cultural, and political circumstances $[26,27]$. In addition, only few of the existing studies, international as well as Swedish, focus on the reform in specific relation to teachers. Indeed, to reach a broader picture concerning effects of the reform, more aspects than students' and parents' choice patterns are needed [14]. However, the consequences of the school choice reform in relation to its effects on teachers are clearly underresearched $[12,18,28]$, specifically when it comes to examining teachers' own beliefs, values, and experiences of working in a context of school choice. In an attempt to meet these concerns, we examine teachers' experiences of effects of the school choice reform in Sweden. Specifically, we examine how Swedish upper secondary teachers in independent (private) as well as municipal schools experience the conditions surrounding their work in relation to the school choice reform. Using sociology of professions as the theoretical point of departure we argue that the teachers' experience of school choice can be interpreted as that the previous balance between the logic of the profession and the logic of the bureaucracy now competes for priority of interpretation with the logic of the market. A clash between the logics can be identified, as teachers often identify stronger with the logic of the profession than the logic of the bureaucracy and the logic of the market.

\section{Background: The Swedish Educational Context}

Why examine the implications of the school choice reform in Sweden specifically? Swedish educational policy certainly has similarities with international policies that encourage 
decentralisation, deregulation, and expansion of choice opportunities [16]. However, there are also differences, as Sweden exhibits a more full-blown "school market" than most other countries [14].

First, the state sets the national curricula for independent as well as public schools. Second, school fees are not allowed neither in independent schools nor in public schools. Instead, a full-scale voucher system is used, so all schoolswhether independent or public_-are funded by the government and the amount of funding depends on the number of students enrolled. Third, although school fees are not allowed, profits are. In fact, there are independent schools that belong to education companies who are publically traded on the stock market, which means that eventual profits can be distributed among shareholders. For example, in 2008 the independent school company Kunskapsskolan had a turnover of 650 million SEK [29]. Interestingly, there are education companies in Sweden who export their "business" to other countries, for example, the UK, which makes the Swedish case highly interesting at this stage (http://www.svd.se/ 2009). The export to the UK has not gone by unnoticed: "the Conservatives' proposal to replicate Sweden's "free school" reforms would be the most radical reform of education in England since the dismantling of selective schooling four decades ago" [30]. Fourth, the expansion of the independent school sector has been rapid, from almost none to about $22 \%$ at upper secondary level in less than 20 years. Moreover, it should be noted that the school choice reform in Sweden coincided with other governance changes such as a far-reaching decentralisation and the introduction of management by objectives, changes that helped pave the way for market-oriented solutions [31]. Fifth, the change in education policy in Sweden has been drastic, spanning from a few independent schools before the 1990s to today where independent schools receive significant support from all larger political parties. The promotion and expansion of the independent schools and the possibility for independent schools to make profits certainly constitute a policy shift in a country traditionally based on social democratic values $[15,32]$. Sweden has a long tradition of social democratic education policy, characterized by a strong central governance with the double aim of increasing the education level among the youth as well as promoting social equity. A slogan was used in the equity strive: "a school for all". This slogan reflected the belief that all students should have the right to the same educational conditions. This was thought to be achieved by the public school system, but there has been some backlash. The introduction of school choice and the possibility for independent schools to establish themselves on the stock market and make profit has been controversial among social democrats. However, in the mid 1980s the social democrats adopted the new liberal discourse, an adoption that was quite a turn for the party [15]. This means that today social democrats and the current right wing government are both promarketization of education, and the value of equity in education is prominent among the various political parties, the left wing as well as the right wing, but the views of how this is achieved differ to some extent.

\section{Theoretical Framework: Different Logics, Different Values}

Professional work, such as teaching, has often been described as situated in a tension between the logic of the profession and the logic of the organization/bureaucracy [3335]. Professionals are governed by the policies, rules, and regulations defined by the work organization they belong to. At the same time, professionals use their professional skills and judgment in their work; that is, teachers, as with all professionals, use their discretionary powers. Indeed, public sector professionals are faced with the dilemma of working in accordance with the values of the profession and with the aims of the work organization $[36,37]$. This tension between different logics becomes particularly interesting during times of changed governance, as with the introduction of school choice. School choice implies adding yet another governance dimension, the logic of the market. By applying sociology of professions as a theoretical point of departure, this study highlights the reform as it relates to how teachers experience the reform. Seen from this perspective, teachers' work is situated in tension between different and, to some extent, competing logics - the logic of the profession, the logic of the bureaucracy, and the logic of the market [38].

In short, the logic of the profession is a governance ideal based on professionals controlling their own work, responsibility, and autonomy, as well as collegiality, trust, a shared profession-specific knowledge base, ethics, and culture. Members of professions tend to have a strong identification with this logic, as the choice of profession is usually an active and conscious choice that is made before choice of work organization. This means that professionals start identifying with the profession earlier than with a specific work organization $[39,40]$. The logic of the profession entails discretionary power, which is a status laden trait, often highly valued by professionals. The logic of the bureaucracy is based on a strong emphasis on managers, bureaucratic procedures with standardization, and evaluation, as well as accountability and efficiency. Coordination and longterm planning are practical examples. Lastly, the logic of the market is based on meeting the customers' (assumed) needs. Concepts such as profit, customers, competition, accountability, efficiency, and managerialism are central. These logics can be seen as "infused with values," to use Selznick's [41] phrasing. In other words, these three logics have different ways of viewing how work should be organized and how work should be planned for, carried out, and evaluated. This means that each of these logics define what is most important and how this is best achieved. The actor(s) that have the priority of interpretation over the operations will influence which logic becomes most influential. One example of a clash between the logics can be described in the form of what knowledge objects the three logics entail [42]. Within the logic of the profession, the knowledge object can be described as the individual students and their needs, which are met via the professionals' specific theoretical knowledge and ethics. Within the logic of the bureaucracy, the knowledge object can be described as reaching the set goals following the bureaucratic structures, and within the 
logic of the market the knowledge object can be described as profit. This means that for a teacher situated in a work context where all three logics are present, she may have difficulties as the logic of the profession (which she is most likely to identify with) may not be the logic with priority of interpretation. For instance, a teacher may identify a need for a student at the same time as the teacher needs to take the organizational constraints into account, such as the bureaucratic structures and resource limitations, as well as she may feel obliged to make the student pass the subject as the school is pressured to display good results.

In Sweden, the education system has traditionally been dominated by a tension between the logic of the profession and the logic of the bureaucracy $[43,44]$. Teachers have had pedagogical as well as administrative responsibilities, a fact that is reflected by the relatively low division of labour in Sweden. We argue that today the logic of the market is becoming increasingly influential, challenging the previous balance between the two logics of the profession and the logic of bureaucracy. As the logic of the market and the logic of the bureaucracy have overlapping values, such as in terms of what they mean by accountability and efficiency, and the state is pro marketization, these two logics can be assumed to be likely to gain priority of interpretation over the logic of the profession.

\section{Methodological Considerations and Case Description}

The paper emanates from an ongoing research project, Upper secondary school as a market, funded by the Swedish Research Council (2007-3579). The project is based on a broad range of data (e.g., statistical data, policy documents, questionnaires, and interviews) that focuses on the manifestations and effects of school choice in upper secondary schools subjected to varying degrees of competition. In this paper, we have used data from interviews with the 58 upper secondary school teachers to highlight how they experience changes in their work context related to market influences.

Five municipal and three independent upper secondary schools were selected in five municipalities: three in the northern and two in the southern region of Sweden. The selection was based on (1) the degree of urbanity of the municipality and (2) expected degree of competition between schools in the municipalities. In municipalities with high degree of urbanity as well as high degree of competition, one municipally run school and one independent school were selected, whereas only municipal schools were available in municipalities with low degree of urbanity (Table 1).

City Public is a large school in a municipality where competition between schools is strong. South Public is a large school that dominates the region. The distance to other strong competitors is relatively long. This fact explains why most teachers do not yet perceive strong competition. North Public is a relatively large school situated in the same municipality as North Independent. For several years, the student enrolment has decreased, which has become a major problem. Regional Public is a large, stable school in
TABLE 1: Overview of the studied schools.

\begin{tabular}{lll}
\hline Degree of urbanity & \multicolumn{2}{c}{ Degree of competition } \\
\hline & High & Low \\
& South Municipality A & South Municipality D \\
& City Public & South Municipal \\
High & City Independent & South Independent \\
& North Municipality B & \\
& North Public & \\
& North Independent & \\
\hline \multirow{2}{*}{ Low } & North Municipality C & North Municipality E \\
& Rural Public & Regional Municipal \\
\hline
\end{tabular}

a sparsely populated region. The distance to other municipalities and potential competitors is far, which explains why most teachers do not experience any marked school competition. Rural Public is a small school in a sparsely populated municipality. It is exposed to strong competition from neighbouring municipalities. Recently, the student enrolment has decreased drastically, which is overriding problem for the staff as there is a risk that the school will have to close down. South Independent is a small school in a region dominated by one large public school (South Public). Three of the teachers perceive competition as strong, while one claims to hardly notice it. North Independent is a small school. There are several public and independent schools in the municipality and there are more openings for students than there are students, which mean strong competition. City Independent is a middle-sized school that only offers academic programmes. The school competition is strong, but the school has been successful as the enrolment has increased.

The selected schools had between 100 and 2000 students and between 10 and 170 teachers; 58 teachers were interviewed in 14 (focus) groups. The choice of interviews as the empirical source is based on the assumption that this source provides insights into teachers' own experiences, views, and opinions [45]. This means that the experiences of the teachers themselves can be illuminated [46]. Focus group interviews in the form of arranged group discussions were chosen since they provide insight through interaction between the participants and thereby create a special dynamic that is difficult to attain through other material collection methods [47].

The initial focus in the analysis of the material was teachers' experiences of the school choice reform in relation to their every day work. The material can be described as based on a thematic analysis [48]. The teachers described their work by contrasting their current work situation with their previous work situation. This approach allowed for an application of the logics inspired by Freidson [38]: the logic of the profession, the logic of the bureaucracy, and the logic of the market. The material mostly addresses the introduction of the logic of the market; this is also the focus in the presentation of the material. This way of handling material is based on an intertwined process between empirical material and theoretical concepts $[46,49]$. 
Further, the presentation of data is descriptive, in that it seeks to illuminate teachers' own experiences of the school choice reform in Sweden. The reason is twofold; first this choice reflects the lack of such studies. Second, this choice is made as it is essential to gain knowledge about teachers' own experiences, as they are the executors of the education mission and as such key actors [50].

As this is a qualitative interview study, the generalisations are analytical [51] so as to understand the teachers' experiences of their working conditions in relation to the school choice reform of upper secondary school. We seek to illuminate specific aspects of these professionals' working conditions to highlight and problematise the complexity of school choice reform. Even if it is not possible to generalise the findings to all teachers in Sweden, the findings may be applicable to and have currency in other similar contexts.

\section{Findings: Competing Logics}

The effects of the school choice reform are clearly reflected in the teachers' accounts of their every day work. The empirical material indicates that the logic of the market has certainly influenced the teachers' every day work, partly clashing with the logic of the profession. The findings are illustrated with quotations from the interviews (translated by the authors). As the interviewees' experiences are rather similar, regardless of working in public or independent schools, and therefore the interviewees' experiences are presented jointly, based on themes rather than comparing public and independent schools. The specific quotations presented reflect the "common view" as well as opposing views.

\section{Expressions of the Logic of the Profession}

The logic of the profession takes departure in that the professionals - the teachers-have higher education in teaching and profession-specific ethics, which makes them best suited to make decisions regarding how work should be planned for, carried out, and evaluated. This means that the professionals enjoy discretionary power based on trust in their theoretical knowledge and practical competence. This also means that the professionals have a large influence over their work. When the interviewed teachers talk about their work and describe how they experience today's work, implicitly even though the focus in the interviews was on the school as a market, a picture is unveiled that points at a strong identification among the teachers with the logic of the profession. It is in relation to the marketization that the teachers' identification with the logic of the profession becomes apparent. One teacher prefers "to use my time directly for teaching" (Rural Public). This is also expressed by another teacher who sees the teaching itself as the core task.

The quality of my teaching would have been better if I did not have to do other tasks as well. (South Independent)
The interviewees express that they feel that their work should revolve around teaching and pedagogy. The interviewees describe how they see teaching as their main task; this is what they identify as being competent with and being committed to.

\section{Expressions of the Logic of the Bureaucracy}

Within the logic of the bureaucracy, the idea is to have a hierarchical organization, where the superior level(s) in the organization has the priority of interpretation of what is the most efficient way of organizing work. Typical traits of the logic of the bureaucracy are the emphasis on following rules and guidelines and conducting evaluations. One example that is brought up by one interviewee is how the management decided to change the organization of the teachers' work from subject affiliation to interdisciplinary work teams.

What we have complained about is that we feel that the subject identity $[\cdots]$ the subject is so important that we feel that the organization of work should be centred around the subjects rather than [the current] interdisciplinary teams. (North Public)

This quotation points at the bureaucratic model's emphasis on "top-down" governance of public organizations controlled by centrally based decisions. It also shows how this logic stands in contrast to the way upper secondary teachers identify with their subjects. Other examples of this logics' presence is when the interviewees talk about how they work with pupil well-being meetings, protocols, development plans, evaluations, and when they discuss insufficiency in resources.

When it comes to filling out various evaluations, there are expressions of this being experienced as a stressful extra task that wastes time rather than provides benefit. In the interviews, there are not many accounts of the logic of the bureaucracy that include discussions about standardisation in form of national tests and evaluations. This can be explained by the fact that the logic of the bureaucracy has for a long time existed side by side, although sometimes clashing, with the logic of the profession; possibly because of its long presence, this logic does not stand out as much as the logic of the market. In addition, the interviews revolved around the issue of marketization and competition.

\section{Expressions of the Logic of the Market}

The logic of the market is based on the idea that market principles make up the most efficient way of running organizations-in this case schools. The "best" schools will survive, and this is based not on political decisions or professional opinions, but rather on the customers' choices. As the influence of the marketization of the education system was the focus of the interviews, the accounts of these experiences are plenty. As mentioned previously, these expressions are often done in comparison with the logic of the profession. 
Instead of discussing how we can improve the students' knowledge, we discuss how we can attract more students. (North Rural)

The presence of the logic of the market stands out in the vocabulary used by the teachers. Terms such as being competitive, selling, marketing, and delivering are used.

There is a very strong market thinking now, on a management level. It became very clear when our new principal held an introductory speech. He talked about competitive advantages, identity, marketing, and so forth. There were several market words. And then, he used teaching once. (North Public)

The presence of the logic of the market is apparent and stands out in relation to what programmes the schools offer. There is a need to adjust to the market, a way of making sure enough students are attracted.

You have to adapt to the teenagers and what they want. Perhaps do a bit of selling as well, like give a subject that you might think doesn't give that much but might attract teenagers. And if you can make them learn others things, it might be worth giving a subject in styling, make-up, spa, or whatever you call it. (North Public)

Furthermore, there are teachers expressing that doing a good job is not enough; teaching has to be showed off as well. One teacher says that today's situation can be compared with being an "advertising sign" (North Independent). It seems the logic of the market influences the everyday work strongly.

I notice that this is a continuous issue, something that we have to take into consideration all the time, questions about competition in orderto be competitive, to have attractive programmes $[\cdots]$ sometimes it may lead to less focus on the education and more on being popular and attracting students. (South Independent)

The significance of competition in the interviewees' everyday work seems to vary; this variation is partly due to the strength of the competition and partly due to how well the school competes for students. Thus, the influence of the logic of the market depends on the local competition situation. It should also be noted that the issue of competition does not seem to be directly correlated with the dichotomy of municipal versus independent school. It is in fact to a larger extent correlated to the actual competitors in the vicinity of the school and what study programmes these competitors have. For example, South Independent competes with South Municipal when it comes to one specific study programme out of 17 programmes in total. In the larger towns, the same study programmes are found in several of the municipal schools as well as the independent schools; hence the competition is between all schools in the area.

\section{Clashes and Overlaps}

The logics presented are ideal types of governance. The logic of the profession along with the logic of the bureaucracy has historically had priority of interpretation, and this is also where professionals' identification is often most strong. The clashes identified in the empirical data are mostly between the logic of the profession and the logic of the market, possibly reflecting that the logic of the profession and the logic of the bureaucracy have "coexisted" for a long time. Below, clashes and overlaps between the logics are presented.

There are interviewees who think that the increased competition has brought a changed organization of work, a focus they are not content with.

It is not organised based on teaching today, rather that issue is given to us teachers, as an individual thing that is suppose to happen of itself. And there are no pedagogical possibilities. There is no pedagogical leadership. [...] There is no such will [from the management]. (North Public)

This quotation shows how the pedagogical foundation is experienced as having ended up in the background. There are several accounts with the same meaning, indicating that the logic of the market has gained ground at the expense of pedagogical work.

Sometimes you can feel like you don't focus as much on education but more on popular things to attract students. And if the knowledge level and education is good, it is not as important in this context; it's more a thing that it has to be popular. (South Independent)

Some interviewees noted that they themselves had to plan for and carry out marketing tasks such as attending fairs and organizing "open house" activities for presumptive students. These interviewees question marketing tasks as being tasks they should be doing, reflecting their identification with the logic of the profession.

I think that we are here to teach and do as good a job as possible and then the marketing should be handled at another level. (North Public)

The new competition-related tasks are essentially not seen as real teaching tasks by these interviewees; they view the new tasks as problematic mainly because these new expectations take time from the core task of teaching (including preparation and follow-up work), and they do not seem to put any positive value with these tasks. In fact, one teacher describes the new tasks as being a "sacrifice" of time, time previously devoted to regular teaching duties. In addition, these teachers do not think they have the competence for the marketingrelated activities.

I don't think we are competent with this. I mean the marketing we can do is to teach well. Being 
involved in logos, brochures, other marketing hype and other things is not our thing as far as I am concerned. (North Public)

The quotation above indicates a clash between the teachers' view of the teaching profession and what it involves and the school organization's view, a clash that can be understood as a clash between the logic of the profession and the logic of the market. In addition, on an overriding level, some question how the two logics of the profession and market go together.

Words like deliver... It's a term from economics. What are we supposed to deliver, democratic citizens and critical thinking, or what? It is difficult to make sense of, and combine, this different language usage. (North Public)

The teachers seem to carry out the new market-oriented tasks with reluctant compliance as they feel they have no choice. It seems difficult for the interviewees to resist taking the issue of competition into consideration as they see a risk of losing their jobs if they do not attract enough students, that is, carrying out marketing-related tasks.

Another clash is between the logic of the bureaucracy and partly the logic of the profession in contrast with the logic of the market, values that include long-term planning and coordination. This goes against the flexibility value on which the market is based. A clear example of this is the possibility to choose schools has resulted in an increase of students who want to change programmes or schools in the middle of the school year. As the study plans of the programmes at different schools are not directly compatible, the teachers have to be very flexible and make great efforts to develop the individual study plans for the students that change programmes or schools in order not to lose the voucher.

Since we need the money, we allow students to come in February [even though the school year starts in August] regardless of pedagogic and educational considerations. (City Public)

This is seen as problematic, as it is disruptive and often difficult to make transitions in the middle of the term smooth and functional. Even though both the logics of the profession and the market are infused with a service ideal, the meaning differs. Within the logic of the profession it is important to give the students good conditions for learning, something that is experienced as difficult with transitions in mid term; whereas within the logic of the market, the service ideal means taking on new students whenever they apply.

As mentioned, some teachers have adopted the logic of the market. What attracts them seems to be the contrast to what they perceive as large, bureaucratic public schools. The flat and flexible organization is appreciated.

Our organization is very flat and $[\cdots]$ flexibility is kind of a prestige word. (North Independent)

The positive experiences of the logic of the market are mainly found among teachers in the independent schools, but also to some extent in the municipal schools. For example, one teacher makes this claim: "I don't think it [logic of the market] is negative always. I think it is a bit of fun too in a way". This teacher sees a positive challenge in trying to identify the strengths of the school. Another example of a rather unproblematized view is in a comparison with other types of jobs.

But there's no difference in selling a school compared to selling Coca-Cola? It's the same crap in the end. [ $\cdots$ ] Yes, I sell education. I used to sell lorries, there's no big difference. (City Public)

This interviewee sees no problem in incorporating values of the market, rather this interviewee finds that the logics can coexist, overlap.

\section{Discussion: Clashing Logics, Clashing Identities}

The results presented in this paper indicate that the Swedish school choice reform has implications with respect to teachers' work. As the teachers' identity much lies within the logic of the profession rather than within the logic of the market or bureaucracy, clashes can be identified. On a practical level, the teachers describe how the pedagogical tasks are now competing with tasks related to competition such as planning for and carrying out marketing of the school by participating, for example, in fairs where they are asked to promote the school profile and the student outcomes and evaluations. Many teachers oppose, oftentimes in silence, the changed content of their work as it goes against what they identify teaching to be.

How then can these results be understood? As with Freidson [38], we have used the logic of the profession, the bureaucracy, and the market as a way of understanding and analyzing how and why upper secondary school teachers in Sweden experience effects of the school choice reform the way they do. It should be noted that the logics used as tools for analysing and understanding the tension described by the teachers in the studied schools are ideal types and as such do not exist in their pure forms. The benefit is that it illuminates how teachers are situated in a tension between different logics. The influence of a new enterprise school culture is evident, for example, as the teachers use concepts such as customer, competition, and marketing when describing their work today. The teachers describe how they try to display "good results" towards their current customers as well as potential customers. The teachers also talk about their work in terms of involving new tasks (marketing related), tasks that they do not think of as teaching tasks, tasks that they do not themselves think they have competence for and which steals time from the pedagogical tasks, which is an example of the clash between logics. At the same time, it is clear that the teachers do not express having a choice of whether to carry out the new tasks or not; that is, they do not have control over the content of their work. The teachers' voices reflect how their autonomy to make decisions about how to use their time is limited. The central issues of trust and responsibility 


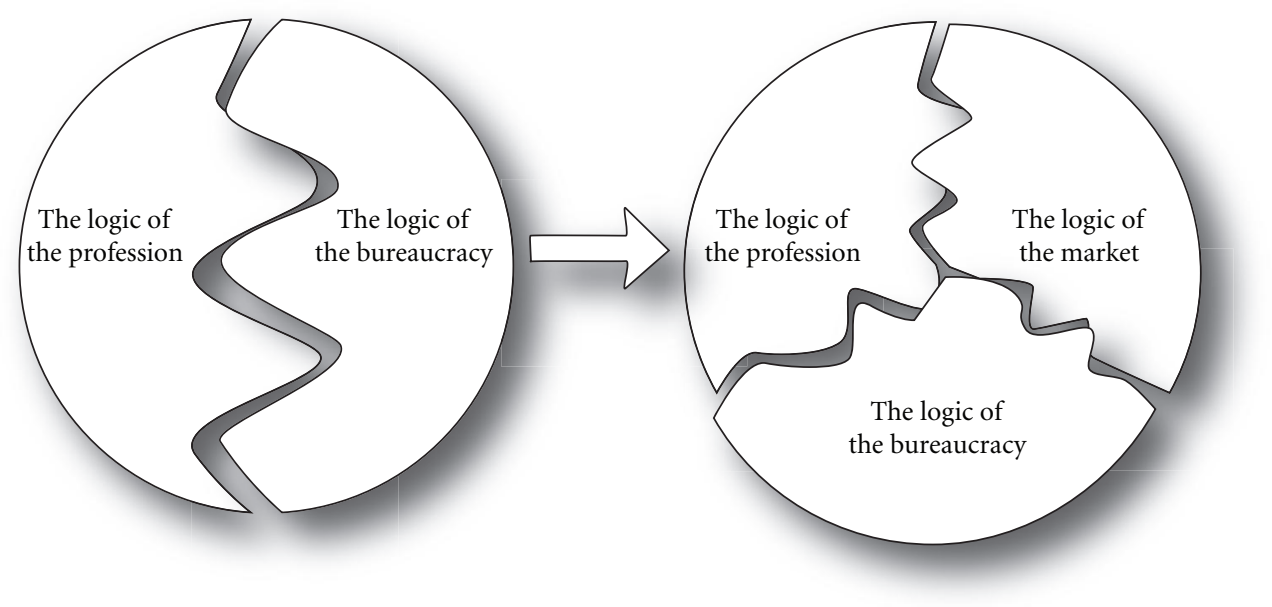

FIgURE 2: Teachers' work: in tension between logics.

for teachers are not given priority of interpretation in the school organizations. Nor does their shared knowledge base (pedagogy) seem to be given priority of interpretation in their respective school contexts. The teachers' "affiliation" with the logic of the profession, infused with values such as autonomy and shared knowledge base, certainly stands in contrast with the marketing tasks emanating from the logic of the market (cf. [38]). The lead words of the logic of the market-competition and attracting customers-certainly have priority of interpretation in the school organizations where the interviewed teachers work.

The study indicates that a division is about to arise in the teacher community as a result of marketization. On one hand, there are teachers who strongly oppose this trend and who defend traditional professional values, that is, the logic of the profession; on the other hand, there are example of teachers who adopt a new professional culture and position, that is, the logic of the market. They value the flexibility, the business ideas, and the entrepreneurial spirit, ideals often in contrast to what they regard as rigid, bureaucratic public school organization.

\section{Conclusions: Effects of the Introduction of School Choice}

The findings in this paper can be contrasted with two previous interview studies on upper secondary teachers in the municipal schools in Sweden [43, 44]. These studies were carried out between 2002 and 2004 in towns where independent schools had not been established at the time, and consequently there were no signs of the logic of the market influencing these teachers in their work. Instead, the tension between the logic of the profession and the logic of the bureaucracy was visible. The teachers were busy handling the implementation of many changes, such as the introduction of a new upper secondary school organization, new curriculum and grading system, together with substantial organizational restructurings such as new work team organizations and new systems for allocation of time and salaries. For instance, the new interdisciplinary work teams, that had been introduced by the school management in one of the studied schools [43], go against the stream of how teachers were traditionally organized; it is well-known that upper secondary teachers traditionally have a stronger identity linked to their specific subject(s) than teachers who do not teach specific subject areas such as lower school teachers [52-54]. This point at the bureaucratic logic, with the idea that interdisciplinary work teams are more efficient, won over the teachers' own ideas, that is, the logic of the profession.

The contrast with the results in this paper is quite remarkable: judging from the teachers' expressions of how they experience their work, there has been a noticeable change in the power balance between different logics that govern teachers' work, a change that has only taken a few years, possibly reflecting the fast and extensive expansion of the independent school sector. Figure 2 summarises the shift of governance of teachers' work that is presented in the findings of this study.

One concrete example of a clash between logics for the interviewees is what their main task should be: selling or educating. An interesting observation in the case of Sweden is that the teachers themselves are in fact planning for and carrying out much of the marketing-related tasks; their teaching mission is coupled not only by actual teaching tasks and regular administrative or bureaucratic tasks, but also to a significant extent by market-related tasks. These new duties may reflect the relatively flat organization structures, with low level of division of labour in Sweden.

What can the long-term effects of the school choice reform-and the introduction of the logic of the marketbe in regards to teachers' work? As presented in the literature overview, the literature on school choice in relation to teachers' work is scarce. What is clear is that often, education policy changes, where school choice is one example, are often discussed in terms of a threat to the teaching profession [7-11]. Using sociology of professions as a framework for 
discussing the school choice reform, it can be argued that there is a potential risk that the collegial support between professionals decreases in times of changed governance.

When individual performance (e.g., of students and teachers, GPs and consultants) is linked to the success or failure of the organization, then this amplifies the impact of any failure. The danger in this is that professional cohesion and mutual cooperation are undermined and competition can threaten both team working and collegial support [55].

On the other hand, as presented in the literature overview, it has also been suggested that school choice in fact brings opportunities for teachers, such as increased autonomy $[3,5]$. Using sociology of professions as a point of departure, it could also be argued that teachers who have a view of their profession as involving pedagogy/teaching as much as marketing, for example, possibly can position themselves in ways that gives them profitable conditions. However, our study suggests a development in the direction towards what could be described with the concepts of organizational professionalism [56] or new professionalism [57], which to the teachers implies a role of a managed, service-oriented worker in a business context. Ball's [7] argument that there is a struggle "over the control of the field of judgement and its values" is certainly present at the schools of the study.

More research is needed to determine the effects of the school choice reform in Sweden as well as other similar countries. Indeed, the Swedish case is also of interest as Swedish education companies, which are allowed to make profits, are about to establish themselves on education markets abroad in countries such as the UK. As a response to Ball's [7] idea about the current reforms changing not only what educators do, but also who they are, one interesting point of departure would be to carry out an observation study to examine how teachers juggle the three logics and thereby study their actual practices; how they juggle the logics in the classroom and in their preparation and follow-up work.

\section{Authors' Contribution}

Ulf Lundström and Karolina Parding have contributed equally to the paper.

\section{References}

[1] Government Bill 1991/92:95, Om valfrihet och fristående skolor [On Choice and Independent Schools9].

[2] Government Bill 1992/93:230, Valfrihet $i$ skolan [School choice].

[3] J. E. Chubb and T. M. Moe, "Politics, markets, and the organization of schools," The American Political Science Review, vol. 82, no. 4, pp. 1065-1087, 1988.

[4] J. E. Chubb and T. M. Moe, Politics, Markets, and America's Schools, Brookings Institution, Washington, DC, USA, 1990.

[5] C. M. Hoxby, "Would school choice change the teaching profession?" Journal of Human Resources, vol. 37, no. 4, pp. 846-891, 2002.
[6] M. W. Apple, Educating the "Right" Way. Markets, Standards, God, and Inequality, Routledge Falmer, London, UK, 2001.

[7] S. J. Ball, "The teacher's soul and the terrors of performativity," Journal of Education Policy, vol. 18, no. 2, pp. 215-228, 2003.

[8] G. Helsby, Changing Teachers' Work, Open University Press, Philadelphia, Pa, USA, 1999.

[9] J. Codd, "Teachers as 'managed professionals' in the global education industry: the New Zealand experience," Educational Review, vol. 57, no. 2, pp. 193-206, 2005.

[10] P. Walsh, "Narrowed horizons and the impoverishment of educational discourse: teaching, learning and performing under the new educational bureaucracies," Journal of Education Policy, vol. 21, no. 1, pp. 95-117, 2006.

[11] G. Whitty, "Marketization, the State, and the re-formation of the teaching profession," in Education. Culture, Economy, and Society, A. H. Halsley, H. Lauder, P. Brown, and A. S. Wells, Eds., pp. 299-308, Oxford University Press, Oxford, UK, 1997.

[12] A. Fredriksson, "On the consequences of the marketisation of public education in Sweden," European Educational Research Journal, vol. 8, no. 2, pp. 299-310, 2009.

[13] A. Fredriksson, Marknaden och lärarna. Hur organiseringen av skolan påverkar lärares offentliga tjänstemannaskap, Göteborgs universitet, Göteborg, Sweden, 2010.

[14] P. Blomqvist and B. Rothstein, Välfärdsstatens nya Ansikte. Demokrati och Marknadsformer Inom den Offentliga Sektorn, Agora, Stockholm, Sweden, 2000.

[15] H. Daun, "Market forces and decentralization in Sweden: impetus for school development or threat to comprehensiveness and equity?" in Choosing Choice. School Choice in International Perspective, D. N. Plank and G. Sykes, Eds., pp. 92-111, Teachers College Press, London, UK, 2003.

[16] H. Daun and P. Siminou, "State, market and civil forces in the governance of education," European Education, vol. 37, no. 1, pp. 26-45, 2005.

[17] L. Lundahl, "Sweden: decentralization, deregulation, quasimarkets-and then what?" Journal of Education Policy, vol. 17, no. 6, pp. 687-697, 2002.

[18] N. Bunar, "Choosing for quality or inequality: current perspectives on the implementation of school choice policy in Sweden," Journal of Education Policy, vol. 25, no. 1, pp. 1-18, 2010.

[19] S. Lund, "Marknad och medborgare-elevers valhandlingar i gymnasieutbildningens integrations-och differentieringsprocesser. [Market and citizen. Student choice in upper secondary school]," Acta Wexionensia nr 82/2006, Växjö University Press, Växjö, Sweden, 2006.

[20] C. Skawonius, Choosing or ending up: practical sense, family choices and pupils' distribution to compulsory schools, Ph.D. Disseration, Stockholms universitet, 2005.

[21] C. Wikström and M. Wikström, "Grade inflation and school competition: an empirical analysis based on the Swedish upper secondary schools," Economics of Education Review, vol. 24, no. 3, pp. 309-322, 2005.

[22] A. Lindbom, Ed., Friskolorna och Framtiden, Institutet för Framtidsstudier, Stockholm, Sweden, 2007.

[23] M. Sandström and F. Bergström, "School vouchers in practice: competition will not hurt you," Journal of Public Economics, vol. 89, no. 2-3, pp. 351-380, 2005.

[24] Swedish National Agency for Education, Data compiled from The Swedish National Agency for Education, 2010, http:// www.skolverket.se/sb/d/175.

[25] H. F. Ladd, "Introduction," in Choosing Choice. School Choice in International Perspective, D. N. Plank, Ed., Teachers College Press, London, UK, 2003. 
[26] M. Forsey, S. Davies, and G. Walford, "The globalisation of school choice? An introduction to key issues and concerns," in The Globalisation of School Choice, M. Forsey, S. Davies, and G. Walford, Eds., pp. 9-25, Cambridge University, Cambridge. UK, 2008.

[27] D. N. Plank and G. Sykes, Eds., Choosing Choice. School Choice in International Perspective, Teachers College Press, London, UK, 2003.

[28] I. Nilsson, Fristående Skolor: Internationell Forskning 19852000, Skolverket, Stockholm, Sweden, 2002.

[29] E. Wahlin, "I en egen klass," in Affärsvärlden, 2009.

[30] R. Allen, "Replicating Swedish "free school" reforms in England," Research in Public Policy, 2010.

[31] N. Stenlås, En kår i kläm-Läraryrket mellan professionella ideal och statliga reformideologier. Rapport till Expertgruppen för studier i offentlig ekonomi. 2009:6. Regeringskansliet. Finansdepartementet, Fritzes, Stockholm, Sweden, 2009.

[32] A. L. Arnesen and L. Lundahl, "Still social and democratic? Inclusive education policies in the Nordic welfare states," Scandinavian Journal of Educational Research, vol. 50, no. 3, pp. 285-300, 2006.

[33] J. Evetts, "Organizational and occupational professionalism: the challenge of new public management," in Proceedings of the 16th World Congress of Sociology, Durban, South Africa, 2006.

[34] J. Evetts, "Introduction: trust and professionalism: challenges and occupational changes," Current Sociology, vol. 54, no. 4, pp. 515-531, 2006.

[35] L. G. Svensson, "Profesjon og organisasjon," in Profesjonsstudier, A. Molander and L.-I. Terum, Eds., pp. 130-143, Universitetsförlaget, Oslo Sweden, 2008.

[36] Y. Hasenfeld, Human Service Organizations, Prentice-Hall, Englewood Cliffs, NJ, USA, 1983.

[37] M. Lipsky, Street-Level Bureaucracy. Dilemmas of the Individual in Public Services, Russell Sage Foundation, New York, NY, USA, 1980.

[38] E. Freidson, Professionalism, the Third Logic, Polity Press, Cambridge, UK, 2001.

[39] Y. Baruch and A. Cohen, "The dynamics between organizational commitment and professional identity formation at work," in Identities at Work, A. Brown, S. Kirpal, and F. Rauner, Eds., Springer, Dordrecht, The Netherlands, 2007.

[40] K. Heggen, "Profesjon og identitet," in Profesjonsstudier, A. Molander and L. I. Terum, Eds., Universitetsförlaget, Oslo, Norway, 2008.

[41] P. Selznick, Leadership Administration. A Sociological Interpretation, Peterson Company, 1957.

[42] A. Liljegren, "Pragmatic professionalism: micro level discourse in social work," European Journal of Social Work. In press.

[43] K. Parding, Upper secondary teachers' creation of discretionary power: the tension between profession and organization, LTU Universitetstryckeri, Luleå, Sweden, 2007.

[44] U. Lundström, Gymnasielärare-perspektiv på lärares arbete och yrkesutveckling vid millennieskiftet, Umeå Universitet, Umeå Sweden, 2007.

[45] S. Kvale, Interviews. An Introduction to Qualitative Research Interviewing, Sage, Thousand Oaks, Calif, USA, 1996.

[46] D. Layder, Sociological Practice: Linking Theory and Social Research, Sage, London, UK, 1998.

[47] D. W. Stewart, P. M. Shamdasani, and D. W. Rook, Focus Groups-Theory and Practice, Sage, London, UK, 2007.

[48] G. Gibbs, Analyzing Qualitative Data, Sage, London, UK, 2007.

[49] M. Alvesson and K. Sköldberg, Tolkning och Reflektion. Vetenskapsfilosofi och Kvalitativ Metod, Studentlitteratur, Lund, Sweden, 1994.
[50] A. Hargreaves, I. Goodson, and J. Sachs, The Activist Teaching Profession, Open University Press, Buckingham, UK, 2003, Series editors' preface.

[51] R. Yin, Case Study Research. Design and Methods, Sage, Thousand Oaks, Calif, USA, 1994.

[52] U. Linnell, "Fortbildning i en decentraliserad skola—en bakgrund och några problemställningar," in Lärares Lärande: Från Fortbildning Till en Lärande Arbetsorganization, T. Madsén, Ed., Studentlitteratur, Lund, Sweden, 1994.

[53] E. Månsson, "Dagens lärare—klämd mellan oförenliga krav?” in Nära Gränsen? Perspektiv på Skolans Arbetsliv, Arbetslivsinstitutet, Ed., Arbetslivsinstitutet, Malmo, Sweden, 2004.

[54] L. Siskin Santee, Realms of Knowledge: Academic Departments in Secondary Schools, Burgess Science Press, Great Britain, 1994.

[55] J. Evetts, "Reconnecting professional occupations with professional organizations: risks and opportunities," in Proceedings of the 9th European Sociological Association, Lisbon, Portugal, 2009.

[56] J. Evetts, "Short note: the sociology of professional groups: new directions," Current Sociology, vol. 54, no. 1, pp. 133-152, 2006.

[57] E. Hoyle, “Teaching. Prestige, status and esteem," Educational Management and Administration, vol. 29, no. 2, pp. 139-152, 2001. 


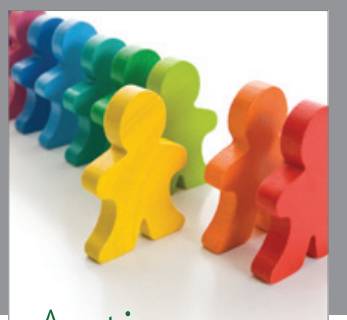

Autism

Research and Treatment
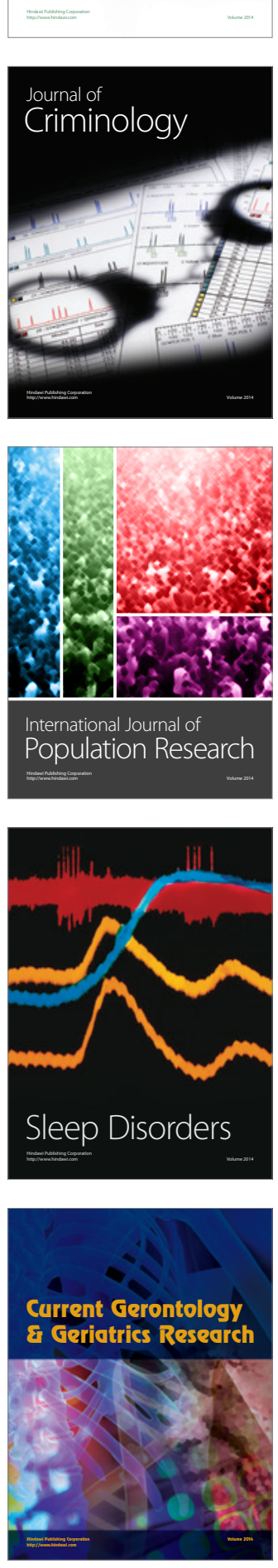
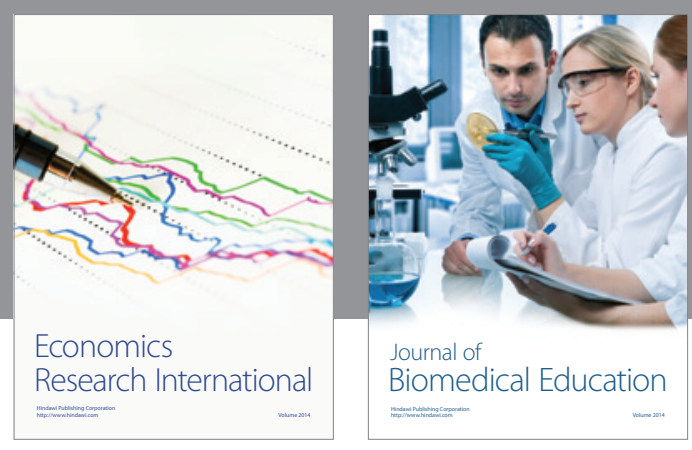

Journal of

Biomedical Education

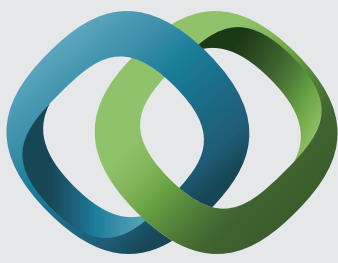

\section{Hindawi}

Submit your manuscripts at

http://www.hindawi.com
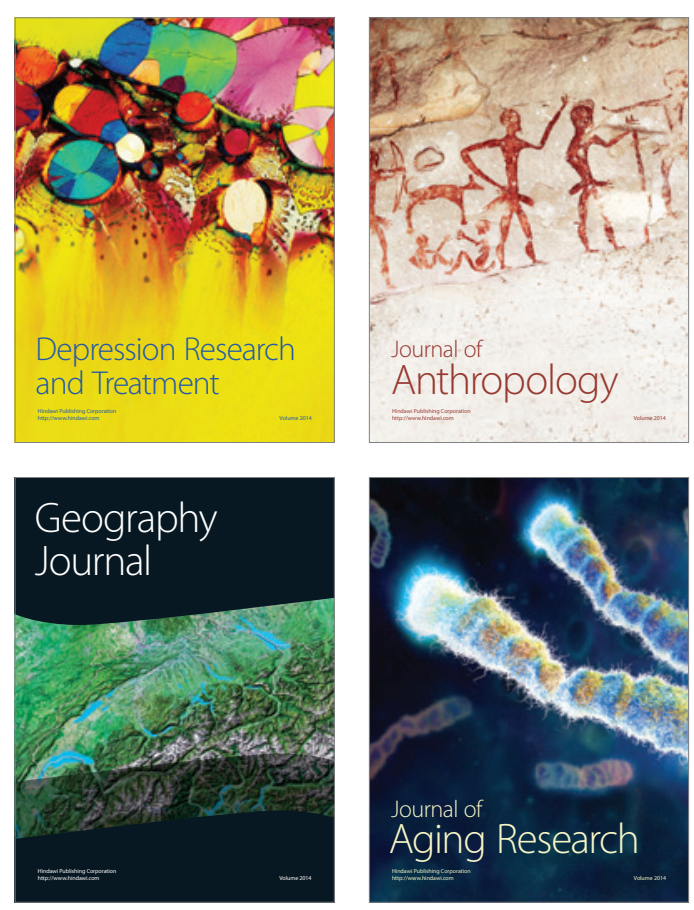

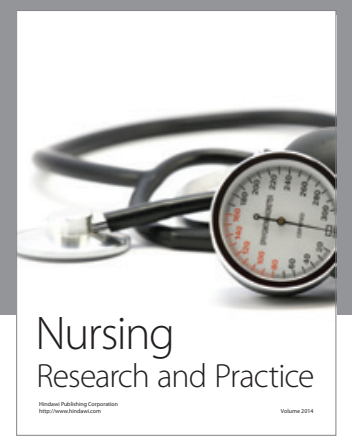

Nursing

Research and Practice

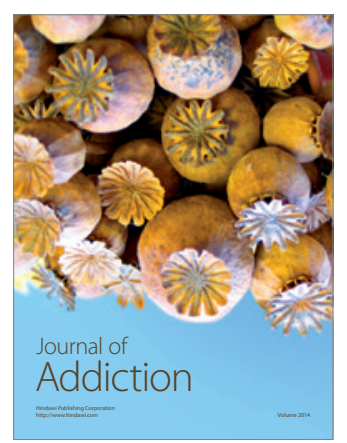

Child Development

Research

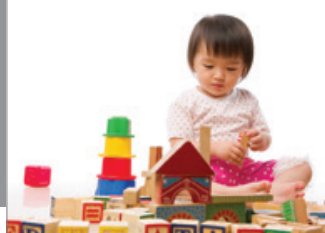

迥
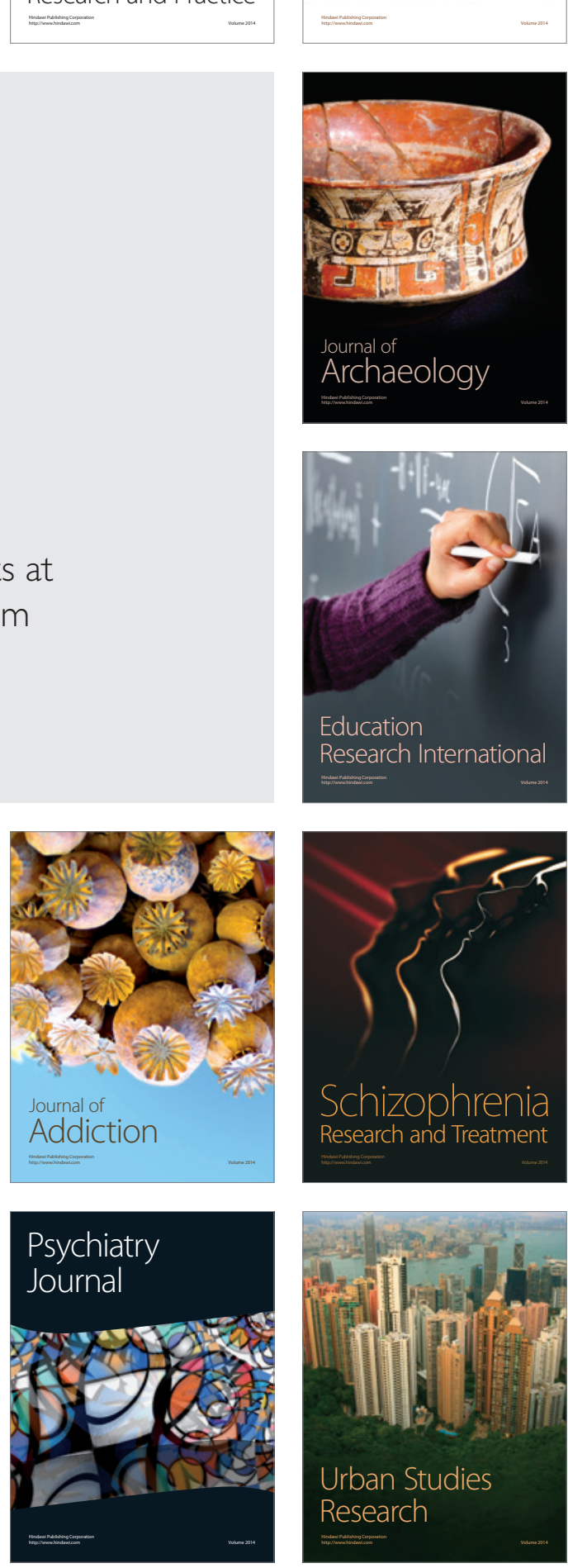